\title{
György Jenei
}

\section{State Sovereignty and National Identity in Hungary}

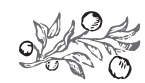

Summary

There is a great debate in the European Union on the present role of nation states, and on the role of state sovereignty on their importance in the future. Some say that the concept of nation states is out-of-date and incapable of facing the challenges of the modern world, while others believe that the nation state is a means of dealing with modern challenges. The key questions of the disagreement are the place and role of nation states in the European Union and the interdependent sovereignty of modern states. This study joins the discussion by reviewing the history of the Hungarian state sovereignty and its ethnical background. The second aim of this paper is to provide a historical contribution to the current discussion with outlining some details of the historical trends and external views on Hungarian ethnicity and state sovereignty.

Keywords: historical challenges and current problems of the modern state sovereignty in Europe, sovereignty of the Hungarian state and its ethnical background, external views on the Hungarians, nation states

György JenEi DSc, professor emeritus, Corvinus University of Budapest (gyorgy. jenei@uni-corvinus.hu). 


\section{György Jenei: State Sovereignty and National Identity in Hungary}

"The Hungarian are living in the healing fever of the times ...... We have no way to escape loyalty. Powers believe living in their systems is good and right, they should allow us to live in our own human and national form. This form will be no more and will be no other than a form of social democracy and national independence. This form, in terms of governance, could be filled by a national government with the will of the people."

(„Hungarian Prayer”. Speech of Áron Tamási, the Szekler-Hungarian writer in the Hungarian Radio Kossuth, on 26 Oktober 1956. On the third day of the

Hungarian revolution and freedom fight.)

\section{THE ORIGIN OF HUNGARIAN STATE SOVEREIGNTY}

Both Hungarian ethnic identity and sovereign Hungarian statehood are of steppe origin. However, they are not the same age. The much more than a thousand-year-old origin of the Hungarian ethnic identity fits into the thousands of years of history of the steppe peoples. Their age is uncertain, but one thing that is certain is that it originated earlier than Hungarian statehood. The Hungarian state - in the form of the Hungarian Grand Duchy - was established at a known date later than György Szabados states: „...Hungary is the only still existing European nation today who were not only the first state organization, but also their ethnogenesis took place in the steppe culture, and which, with this Eastern heritage, integrated into the intellectual-political world of the medieval 'West' and expressed within its own state and ethnic characteristics" (Szabados, 2015, p. 159).

Many historians agree that the most eastern living pre-Hungarians belonged to the group of Ugric peoples living in the forest zone in Asia, who then slid down into the steppe zone, which is south of the forest zone. In other words, the Ogur Turks, also known as the Bulgarian Turks, slid into the steppe area beyond the Urals, where the pre-Hungarians lived, even more eastern than the Mansi and Khanty peoples. The consequence of the cultural influence was that the pre-Hungarians changed from a one-sided hunter-fisherman group to an animal-keeping and even animal-breeding people. This has been proven by linguistic research results (Deér, 2007, p. 30).

Based on the existence of the folktales among the Hungarians at the time of the conquest of the Carpathian basin (895 A.D.), it cannot be ruled out that the people with Hungarian ethnicity already existed as part of the Hun Empire (Gombocz, 1921; Hóman, 2010). After all, the oral tradition among the peoples of the steppes has persisted for several centuries. The oral traditions among the steppe nomads last usually for many centuries. An obvious example for this is that in today's Hungary, the living oral tradition of the Kun tribes and their Kun origin, or the oral tradition of the Jazigs that lasted for centuries regarding their Iranian origin and their relations with the Ossetians living in the Caucasus. So much is obvious that the topic is worth further scientific research.

This is confirmed by Péter Váczy's research on the Empire of the Huns. Addressing the origins of the steppe peoples, he points out that the folk name in the steppe empires is given by the conquering people or tribe. So the name does not mean eth- 
nic homogeneity. For example, as Váczy writes: "The first of the eleven tribes of the Uyghurs in the rank, was the Kagan tribe. They were the 'Uyghurs', hence the name of the entire tribal alliance was Uyghur" (Váczy, 2010, p. 60). The name Hun also meant ethnicity, but "...many times the name Hun just meant that the person was member of the Hun Confederation" (Váczy, 2010, p. 61).

The situation was similar of that of the Huns and Uyghurs in the Turkic, Avar, and Khazar Empires, where the Turkic, Avar, or Khazar were the naming ethnicities of the sovereign state based on their dominant position in the empire. However, other ethnicities with independent identities were also integral parts of these empires, possibly including groups with Hungarian ethnic identities. The consequence of the cultural influence of the people living in the steppe was that the Hungarians were thus included in the westward rotation of the nomadic tribes (Györffy, 1999, p. 60).

The pre-Hungarians were not divided as servants among the individual ethnic groups but formed an independent ethnic identity in the Ugric-Bulgarian-Turkish folk composition, as a separate Hungarian group.

Their Hungarian language proves that they were not absorbed but lived as an ethnic group with an independent identity among the Ogur Turkish peoples. As József Deér states: "The survival of their language can only be explained by the assumption that they formed a separate tribe in the Bulgarian-Turkish political organization, because if the Hungarians had been divided as slaves among the conquerors, the FinnoUgric language would have disappeared without a trace, and the Carpathian Basin would have been taken over in 895 A.D. by a people of a completely Turkish ethnicity and Turkish language" (Deér, 2010, p. 36).

During the wave of more centuries of migration from the East to the West, Hungarian heterogeneity expanded due to Mongolian and Oguz Turkish (Hun and then Avar) coexistence, which expanded further including new ethnicities such as the Alans, Sogdis, and Sarmatians of the Iranian ethnic group during the steppe migration (for a detailed description of the historical process in the steppe zone, see Hóman and Szekfú, 1941, pp. 23-32).

The heterogeneity of the Hungarian people became even more colorful after the settlement in the Carpathian Basin, as Mihály Babits wrote: "...the Hungarian people did not arise from the unification of two or three varieties of people, such as the English one, but from the merging of countless small species fragments into one stronger tribe. As such, it has become more unified and yet more diverse than many other peoples in Europe, both in its soul and in the culture that expresses it in its soul" (Babits, 1939, p. 52). The Hungarian Grand Duchy was founded as a steppe power when the Hungarians (9 tribes) led by the tribe called "Megyer", felt enough force to secede from the Khazar Empire, and at the same time they entered that stage of history as an independent empire.

From the founding of the Hungarian Grand Duchy on the steppe, Hungarian identity became a double meaning. It represented the ethnic group with Hungarian ethnic identities (the name of the steppe tribe became the "megyer" tribe), but Hungarian identity also indicated a heterogeneous empire, in other words: a state, 


\section{György Jenei: State Sovereignty and National Identity in Hungary}

which was based on the importance of the Hungarian ethnicity bringing together and organising groups with an identity that often spoke another language as well. This state followed the Hun, Avar, Turkish, and Khazar patterns, and at this point the Hungarians became a real nation (Deér, 2007, p. 40).

The location of that event was in Etelköz during the 8th century, where the Hungarians found themselves in a life-threatening situation, as József Deér states: "Etelköz was a large cemetery of the nomads heading west, where they had already collided with the ring of those who had already settled there and had been faced with the pressure of their eastern relatives. The consequence was that they were being wiped out in battles fought on both sides over a few decades. The Hungarians were threatened with the same fate as the nomads, which later also affected the Pechenegs, Uzes, and Cuman tribes in this region" (Deér, 2007, p. 39).

Leaving Etelköz in 895, the Hungarian Grand Duchy avoided being wiped out by occupying the Carpathian Basin.

\section{THE FORMATION, SOVEREIGNTY AND STRENGTHENING of the Ghristian Hungarian Kingdom}

After the occupation of the Carpathian Basin, the Hungarian Grand Duchy became a significant European power over the centuries as a Christian Kingdom of Hungary, and the dominant role of the Hungarian ethnic group remained unbroken in this empire, while its original heterogeneity expanded with new ethnic groups. At this point, it is worth dispelling a common misunderstanding: in the case of the Hungarians, the adoption of Christianity was not a passive acceptance, however the apostolic Kingdom of Hungary, since its establishment, was an active factor for shaping Christianity. The Hungarians, like the steppe peoples, did not dogmatically refuse monotheism. As József Deér points out: "The Hungarians were torn from a cultural circle in Europe whose peoples had a high-level experience of God... Our Bashkir relatives who remained in the East - besides the spirits of nature - prayed primarily to the God "who dwells in heaven' and 'whom' is considered superior to all the spirits of nature" (Deér, 2007, p. 61). The Christian world was not superior to the Hungarians. In fact, the 10th century can be called the "dark age of Christianity" as Nemeskürty writes: "Between 882 and 992, eight popes were murdered within a hundred years, mostly by their fellow priests, who were their rivals of power" (Nemeskürty, 1994, p. 9).

The history of the Kingdom of Hungary is unique to Europe in two respects. On the one hand, unlike the empires that previously ruled the Carpathian Basin (such as the Hun and Avar predecessors), it did not cease shortly after its founding. The Germans - remembering Charles the Great's series of campaigns to destroy the Avar power in the Carpathian Basin - attempted to destroy the power of the Hungarian Grand Duchy shortly in 907 but were defeated in the battle of Bratislava and had to retreat all the way to the Enns River. They renounced, for a short time, the offensive wars against the Hungarian Empire. The occupation of the Carpathian Basin then became a conquest. 
On the other hand, Hungarian statehood is unique because the current sovereign European states were founded under the influence of either Rome or Byzantium and following their patterns and ideologies, while Hungarian statehood originally followed the pattern of steppe established statehoods and has historically survived to the present day with a unique adaptation and continuity of ethnic identity. In other words, nowadays the sovereign Hungarian state is an exceptional power formation in Europe. For the first time, the statehood of the Hungarians who settled in the Carpathian Basin successfully led the spoils of war against the Christian powers of Europe which was typical of the steppe powers. However, it has been at a crossroads since the middle of the 10th century (Hóman, 1941, p. 180).

Prince Géza therefore took proactive steps towards adapting to Christian powers. This not only opened the possibility of survival for the Hungarian ethnic identity, but also initiated the transformation of the Hungarian empire. Continuing this direction, St. Stephen transformed the Hungarian Grand Duchy into a Christian Hungarian Kingdom. The Hungarian Empire thus gained its sovereignty and opened opportunities for the development and fulfillment of all the subjects of the kingdom, regardless of their ethnic and linguistic affiliation. Hungarian state sovereignty was unique in Central Europe.

The Hungarian King received the Holy Crown from the Pope, which meant that he avoided any feudal dependence from the German-Roman emperor and any other European power. This has not been the case with other emerging state formations in Central Europe.

The sovereignty of the Kingdom of Hungary was made indisputable by the fact that Pope Sylvester - in the words of Bálint Hóman - "sent Saint Stephen the requested royal crown and the 'apostolic cross' with a long handle on it, as a symbol of his conversion mission, organized independently from the ecclesiastical organization of foreign countries, and organized directly under the Roman Holy See" (Hóman, 1941, p. 180). Otto the 3rd, the German-Roman emperor recognized the sovereignty of the Christian and apostolic Hungarian kingdom by gifting Saint Stephen the spear of Saint Moritz of Thebes, decorated with a holy relic from the cross of Christ.

Together, the Holy Crown, the Apostolic Cross, and the spear meant the sacredly established sovereignty of the Kingdom of Hungary as it fully symbolized and expressed the recognition of all the European states existing at that time, in accordance with the requirements of the Early Middle Ages.

In the following centuries, the sovereign Hungarian state, the Kingdom of Hungary, was strengthened. The sovereign Kingdom of Hungary became a significant European power. It did not follow the pattern of any other European Christian power - it was not assimilated but integrated - but created a Christian state that became an active component of the Christian Europe, and acted as a bulwark of Christianity from the Ages of the Tartar invasion. Until the death of King Matthias, Hungarian state sovereignty was strengthened, and the Kingdom of Hungary became a European superpower. 


\section{György Jenei: State Sovereignty and National Identity in Hungary}

\section{European opinions about Hungarians in the Early Middle Ages}

Like other historical stages, it is characteristic of this period that a thorough overview based on empirical data of the Hungarians, and the Hungarian history is contained in various social science works, studies and monographs. On the other hand, the first recollection of the Hungarians which was institutionalized in the literature of the medieval chronicle and influencing public thinking, was founded by Father Regino when he wrote about the Hungarians invading Germany, saying that "according to news, Hungarians eat raw meat, drink blood, and tear out the enemy's heart to strengthen their courage" (quotation from Eckhardt, 1992, p. 88). Who did this news come from? Regino worked with a template which the Christian West characterized pagan peoples. The origin of the template goes back to Justin. The medieval chroniclers and yearbooks also followed Regino's opinion, copying and extracting opinions from each other. Sándor Eckhardt, who was dealing with the foreign view of the Hungarians, lists the main stages of the spread of the Hungarian image. He said, that a lot of chronicles, for instance the "Saxo yearbook writer, the Actuarium Garstense, Saint Trudparti's yearbooks, Actus Brunwilerensis, Adam Bremen, The Great Belgian Chronicle as jays repeat these incompetent perceptions" (Eckhardt, 1992, p. 89).

This schematic pattern was followed by the well-known opinion of Bishop Otto of Freising, who passed through with the Crusaders in Hungary, about Hungarians (Eckhardt, 1992, p. 97-98). The explanation of this schematic picture is that the European powers shaped their opinion about the people of the Kingdom of Hungary, as well as the Hungarian ethnic identity according to their own interests. Their position was basically hostile and contemptuous. The starting point was the policy of the GermanRoman Empire, which considered the Carpathian Basin to be a German province.

The hostile feeling of Christian Europe was justified when the Hungarians conquered the Carpathian basin, because the feeling of pagan Hungarians was similarly hostile towards the Christian Europe (Deér, 2007, p. 28). On the other hand, the view for centuries was that Hungarians were just Asian barbarians - but this was ceasing. Stereotypes had been followed, stigmatized, and the patterns of antique templates created earlier about barbarian peoples were drawn on Hungarians who have taken up Christianity in the meantime. This view only changed when the Christian European state needed Hungarians. As such, for the first time, according to the official Byzantium - who once needed the Hungarians against the Turks - the Hungarians were no longer barbaric beasts but had become brave and daring warriors.

The decisive role of the interests is shown by the fact that the Germans, who fought the Hungarians several times since the Battle of Bratislava in 908, continued to be averse to the Hungarians. As mentioned, the Germans organized themselves into an empire and carried out numerous attacks and campaigns against the Kingdom of Hungary that had been strengthened and which was considered to have been dangerous. At the same time, they did not give up their territorial claim to the Carpathian Basin. Therefore, they needed to draw an antagonist image, which was artificially produced by the chronicle writers. 
Civic Review · Vol. 16, Special Issue, 2020

This fundamentally negative image only changed centuries later during the struggles against the Turks. This time, in a positive direction, and the Hungarians appeared as noble defenders of Christianity.

The development of Hungarian ethnic identity was not at all influenced by the changes of external perception - it was clearly based on the Christian values and selfawareness driven based on this. This was primarily achieved by social psychology and everyday thinking, and in addition to Christianity, the steppe traits also survived. The Hungarians considered their own ethnicity within a larger Christian community in Europe to be a self-conscious and equal part (Keresztury, 1992, pp. 142-143).

State sovereignty in Europe during the Early Middle Ages.

Historical antecedents of Westphalian sovereignty ${ }^{1}$

In current everyday thinking, the terms state and sovereignty are intertwined.

However, the etymological origins of the two Latin terms are different. The origin of the term state comes from the word status in ancient Latin, and in many European languages (state, der Staat, etc.), the original Latin word can be recognized. On the other hands, the origin of the term sovereignty comes from the word superanus in ancient Latin. This term first appeared in southern Europe, and then in the Germanspeaking world in the 11th century (Conze and Boldt, 1990, p. 70).

In the interpretation of medieval states, sovereignty meant an exclusive transcendent dependence on an otherworldly power.

Non-sovereign states on the other hand, were, in addition to transcendent dependence, in a position of feudal dependence to some worldly power. Medieval states were dynastic powers that changed depending on the evolution of power relations between dynasties.

\section{TERMINATION OF HUNGARIAN STATE SOVEREIGNTY. THE IMPACT ON HUNGARIAN ETHNIC IDENTITY}

After 1490, the sovereignty of the Christian Kingdom of Hungary collapsed. As a combined effect of the expansion of the Ottoman Empire and the Habsburg Empire, Hungarian state sovereignty left the country in two directions, to Vienna and Istanbul. The Habsburgs maintained the Kingdom of Hungary in the sense of public law but relocated its functions of power over to Vienna. On the other hand, was brought under the rule of the Turkish Sultan. As the Sultan wrote in his letter to the French king, "By the grace of Almighty God, we have subjugated Hungary to the bright rule of our great majesty" (quotation from Nemeskürty, 1996, p. 34). The Turkish occupation was tolerated only the autonomous Transylvania, with rights limited to the administration in a subordinate situation until the end of the 17th century. Following that, the Turkish influence ceased.

Hungarian state sovereignty ceased for centuries and apart from a few episodic aspirations and appearances, was only reestablished after 1920. This meant that Hungarian ethnic identity was formed in the absence of Hungarian state sovereignty until 1920. 


\section{György Jenei: State Sovereignty and National Identity in Hungary}

\section{Hungarian identity during the Turkish occupation}

The first consequence was that the unified Hungarian identity had disintegrated.

The spread of different trends of reformation in the village people resulted in the fact that the ability to read and write in the Hungarian language had strengthened the Hungarian identity. A peculiar symbiosis was established between the Hungarian language and the trends of the reformation. The Hungarian language originally expressed our separation that originated from the East.

Galeotto Marzio had noticed that, unlike Italian speakers, who did not understand each other even within the Bologna region since their spoken language is so different, Hungarians understood each other widely (Nemeskürty, 2003, p. 37). The intertwining of the reformation and Hungarian identity was expressed by the fact that Bible translations became more and more widely known amongst people. The Hungarian Reformation was a fundamental sustaining force of Hungarian identity, and at the same time provided the Hungarians with a European rank. The statue of Prince István Bocskai also indicates this in the Geneva monument of the Reformation.

However, the whipping of Hungarian mistakes and backwardness had also appeared.

The prominent personalities of the country - regardless of party and religious affiliation (Zrínyi, Nádasdy, Eszterházy, Bethlen, Pázmány) - also explained the disintegration with national issues. The country's and geopolitical situation of Hungary was not seen as a sufficient explanation for this. This had two consequences. On one hand, a terrible vision of the threatening and fatal death of the nation appeared in Hungarian identity (Keresztury, 1992. pp. 145-146). On the other hand, the search and analysis of the causes not only triggered a vision of national death, but also became a source of a strong sense of Hungarian identity, in which the concern for our destiny stimulated the struggle for freedom.

The vocation of the struggle for the survival of the Hungarians is based on the Christian feeling that Hungarians consider themselves God's people, who must endure God's punishment for their sins, but if they want to remain sons of God, they must fight. The consciousness of the Hungarians, and the desire for freedom rested on sacred foundations. Due to its sacred nature, Hungarian Christianity - both Catholics and Protestant denominations - opposed Muslim Turks. This folk survival meant the survival of Christianity.

István Bocskai, Gábor Bethlen, and Miklós Zrinyi got the furthest on this road. All three set the restoration of the Hungarian Empire as a hidden goal, relying on Hungarian forces on the basis of the struggle for independence against the Habsburg and Ottoman Empires. This failed for various reasons.

At the end of the period of Turkish occupation, another feature of the strengthening of Hungarian identity appeared: the distancing, and even resentment to the west, mainly due to the violence of the Germans. This brutal violence culminated during and after the expulsion of the Turkish troops, where it reached its culmination, which was described in the writing of Judge Flämkitzer. Gyula Szekfú quotes this as he writes, "Hungary is full of the terrible blackmail of the German army, its insatiable actions, 
Civic Review · Vol. 16, Special Issue, 2020

its utter arbitrariness, inhuman clashes, just so books could be filled with descriptions of such violence and barbaric ruthlessness" (Hóman and Szekfú, 1935, pp. 248-249).

The power of the Hungarian identity was weakened by the fact that the self-consciousness of the Hungarians began to split in two after the disintegration of the Kingdom of Hungary. Hungarians representing Turkish and Habsburg orientations opposed each other, either in a way that supported the constructive goals of the Turkish Empire or the Habsburg Empire, even in opposition to each other. In the 17th century, it appeared in contrast of the "kuruc" and "labanc" orientation.

The purpose of the Kuruc identity (the term kuruc is of Turkish etymological origin, who called the rebels and the insurgents kurusj) was to restore the sovereign Hungarian imperial statehood as a result of the struggle for independence against the Habsburg Empire, even with the political support of the Ottoman Empire. They trusted that Porta would not interfere in the internal system of the Kingdom of Hungary. On the other hand, the Labanc identity (the etymological origin of the term "lobonc" referred to the German wig wear, see Nemeskürty, 2003, p. 66), renounced Hungarian independence and contended with the preservation of the formal functioning capacity of Hungarian political institutions. The two identities accused each other.

The kurucs accused the labancas with betrayal, and the labancas accused the kurucs with chasing unreal dreams. At the lowest point of the confrontation, they even clashed with weapons. The opposite view, came to the fore in 1664, when in the battle of Szentgotthárd, forces demanding Turkish support spoke for Turkish victory, while Habsburg parties fought against the Turks on the side of Montecuccoli.

\section{European opinions about Hungarians during the Turkish occupation}

Although the barbarism and backwards view of the Hungarians was still a recurring theme from the very beginning, external judgment had been the dominant image of the Hungarians as the glorification of the bastion of Christianity. The change in views was very well characterized by the writing of Machiavelli, where he speaks about the role of Hungarians: "Hungary's inhabitants, being warlike serve as a bastion, so that the Scythians who are bordering on them do not dare to believe, that the Hungarians could be defeated and broken through. Often large Tartar attack movements were organised, which were then arrested by Poles and Hungarians. They also often boast about it, if they had not had their weapons, Italy and the Church would have felt the weight of the Tartar armies on several occasions" (Terbe, 1936). The role of the Hungarians as a bastion was also related to the fight against the Turks, and many people were grateful for this role. This gratitude was expressed in German, in French and Italian sources, which expressed the glorification of the bravery of the Hungarians. However, there were also regular opinions that Europe would have been not grateful, as the Hungarians had only defended themselves.

In the last decades of the Turkish occupation - seeing the divided and weakened Hungarians - the hostility of the Habsburgs intensified, which was helped by the fact that Kuruc troops fought on the side of the Turks during the siege of Vienna. 


\section{György Jenei: State Sovereignty and National Identity in Hungary}

As a result, in 1688, the year of the recapture of Buda Castle, the work of the then Bishop of Gyôr - the later Hungarian prince-primate - Count Lipót Kollonich (in his language titled Einrichtungswerk des Königreichs Ungarn), was published, which established the Habsburg colonial policy. It started from the premise that the Hungarians, after not having been able to liberate themselves, lost their right to establish an independent state.

Hungary was considered a conquered province, and after the expulsion of the Turks this principle was enforced, as exemplified by Nemeskürty: "Jászkunság was given as a gift to the German Order of Knighthood (1702), Hungarian wine export and silk brokerage trade were granted to the English company Sedgewick as a licence, and beef exports were taken over by an Austrian oriental company" (Nemeskürty, 2001, p. 300).

The New Acquisitions Commission usually did not return the liberated territories to the old Hungarian owners, but instead to army transporters, military commanders, and court officials. Additionally, they did not repatriate the Hungarian indigenous population to the depopulated areas, but divided the estates among the newly settled Serbs, Slovaks, and Germans.

\section{The MOdern, SOVEREIGN EuRopean STATE IN Europe AND HUNGARY}

The theory debate that took place during the Middle Ages also paved the way for Westphalian sovereignty.

\section{The theoretical discussion ${ }^{2}$}

First, the transcendent view of Jean Bodin (1530-1596) was disputed by Johannes Althusius, ${ }^{3}$ arguing that the owner of sovereignty (i.e. political supremacy), is not the ruler but the people. As an alternative to transcendent sovereignty, popular sovereignty has emerged as a determining factor (Kunzmann et al., 1999, p. 101).

The immanent approach was completed by Hugo Grotius (1583-1645) by changing the transcendent interpretation of natural law into an immanent approach. This meant that people formed communities organized by their mind and social instinct, and were able to agree on what was in harmony with their divine nature. That is, according to Althusius and Grotius, state sovereignty derives from popular sovereignty.

This debate has also arisen in various theories of social contract. In Thomas Hobbes's (1588-1679) conception, the power of the state is unlimited, inalienable, and indivisible (Kunzmann et al., 1999, p. 117), but John Locke (1632-1704) argues that natural law forbids the harming of lives, health, liberty, and property of others. This society is therefore not a set of isolated individuals. In a social contract, people create a state as a community force that, while superior to them, is bound by natural laws. If the higher power breaks the laws, the people can replace it, even by using revolutionary violence (Kunzmann et al., 1999, p. 121). 
Civic Review · Vol. 16, Special Issue, 2020

The starting point of David Hume's (1711-1776) theory of the state is that the individuals seeking to acquire and possess wealth, needs peace and security to preserve his wealth. They create a legal order that ensures peace and security, because that is the only way they can limit the conflicts that exist between people because of the scarcity of material goods. This principal power was created on an immanent basis, in order to assert the benefits of society as a whole by framing individual aspirations on the basis of fidelity to justice (Kunzmann et al., 1999, p. 127).

Jean-Jacques Rousseau's (1712-1778) theory of state is a completely inherent theory. In fact, it is also a social contract theory in which Rousseau introduces the category of public will and makes every human's will a part of the public will. The public will give expression to popular sovereignty. That is, popular sovereignty comes from the social contract, not state supremacy. Laws are valid only if they are in accordance with the public will. Otherwise, they are only violent, individual instructions that are not binding on the individual. People's sovereignty is enforced by an executive power controlled by the public will, and if it deviates from this, the public will is enforced against the executive power, and if necessary, by revolutionary action (Kunzmann et al., 1999, p. 133).

Rousseau's theoretical position closed and summed up a centuries-old theoretical debate and expressed his position on the inseparable relationship between state sovereignty and popular sovereignty with valid effect to these days.

\section{The modern European territorial state with Westphalian sovereignty}

Scientific literature agrees that the modern sovereign European territorial state was created at the end of the Middle Ages, after 1648, based on the so-called Peace of Westphalia, which was otherwise concluded in the cities of Münster and Osnabrück. Westphalian sovereignty defined individual states as holders of internal supreme power over a population living in a clearly defined area. At the same time, it obliged states to mutually recognize each other's internal supremacy, that is, not to interfere in the exercise of the supremacy of other states.

The Peace of Westphalia, which ended a devastating 30-year-long war, marked a turn by shifting the focus to an immanent relationship between the individual European states, however the absolute monarchies and enlightened absolutisms that concluded the treaty, also retained transcendency. In absolute and enlightened monarchies, there were no citizens, only subjects, so we cannot talk about internal sovereignty.

The modern European states have developed a formulation that combined coercive features (law and order, war) with economic organizational activities (taxation, trade) in such a stable way that allowed for more effective responses to historical challenges, such as city-states and urban leagues. This stable connection is called the state interest.

Sovereignty is the essence of territorial state, not just a property of it, and this is still valid today. Sovereignty entitles it to exclude all other states from the exercise of the internal rights, and to exercise the rights of sovereignty freely and, if it deems to 


\section{György Jenei: State Sovereignty and National Identity in Hungary}

be necessary, to transfer the rights as well. The extent and timing of the transfer is the sovereign right of each nation state. Sovereignty extends in both the vertical and horizontal directions. The vertical direction is expressed in the extent to which sovereignty limits the individual as a citizen.

The horizontal direction refers to areas of institutional practice that are inseparable from sovereignty. These include diplomacy, tax collection, foreign trade, and immigration control.

We distinguish between the internal and external dimensions of sovereignty. The internal dimension defines the range of people and resources that are valid in a defined geographical area. The external dimension determines the international obligations of the state, and the scope of activities that the state may or may not do in the international relations.

Although the Peace of Westphalia declared external sovereignty, the states regularly violated this in historical practice. They continued the medieval tradition of regularly and armedly seeking to change the boundaries, and to limit or destroy the internal supremacy of other states.

Modern statehood certainly meant stability against the instability of medieval states. However, the relationship between state sovereignty and popular sovereignty remained open and was raised in the individual state dimension. The basic question is: does popular sovereignty underpin state sovereignty, or does state sovereignty limit popular sovereignty on ethnic, political, or social grounds?

\section{Hungarian sovereignty in the modern times}

During this period, the sovereignty of the Hungarian state did not exist, but the political activity of the Hungarians was confined within the framework of the Habsburg Monarchy with limited autonomy. Until 1920, the sovereignty of the Hungarian state was raised in two historical episodes, in the framework of an open national uprising and war of independence. Once, as an aspiration of the Rákóczi War for Independence in 17031711, and secondly at the Hungarian Revolution and Freedom Fight of 1848-1849.

In the Rákóczi War for Independence, the openly undertaken goal of restoring the sovereign, historical Hungarian Empire failed. This closed a chapter. It became clear that the struggle for independent Hungarian statehood was unrealistic. The Turkish Empire was pushed back to the Balkans, and the remaining Hungarian political institutions within the dominant Habsburg Empire represented exclusively the realistic political space and opportunities for the activities of the Hungarians.

The survival of the Hungarians became questionable and there was a real danger that they would disappear and be absorbed like the peoples that arrived earlier to the Carpathian Basin. However, under the reign of Maria Theresa, a number of economic and cultural opportunities opened up for the Hungarians. Hungarian identity was a motivating force before the ascension, by revoking the previous repressive measures (abolition of the New Acquisition Committee, expulsion of the German Order of Knights in 1745). Maria Theresa created further favorable conditions for the strength- 
Civic Review · Vol. 16, Special Issue, 2020

ening of Hungarian identity. The identity was strengthened by the integration of settlers of other nationalities - who begun to speak Hungarian among each other - into Hungarian society. The miracle of the ascension was also noticed by foreign observers. This was also expressed by Paolo Renier, Ambassador of the Venetian Republic in Vienna (Nemeskürty, 2001, p. 318).

At the same time, the duality of Hungarian identity prevailed. Habsburg modernization was accompanied by efforts to Germanize the Hungarians. One Hungarian identity opposed Germanization and therefore also rejected modernization. With this, he not only defended the attacks against the Hungarians, but also achieved the unfolding of a significant part of the settlers. The other identity accepted Germanization because of the rise in economic prosperity. The two identities sharply and mockingly condemned each other's behavior, but there was no armed conflict between them.

\section{The external image of the Hungarians in the 18th century}

The public opinion of the German-speaking area by the Hungarians was contemptuous. Then the Hungarians gradually gained strength. According to this, Hungarians can only fight, but otherwise they were unpretentious. They were assumed to not understand about cultivating land and are incapable to develop their minds. This is aptly described by Nemeskürty when he describes that Jakob Friedrich Reichmann, in his universal literary history, questions the existence of Hungarian literature because "Hungarians value a good horse or a bright sword more than a valuable book" (quotation from Nemeskürty, 2001, p. 311) The original German title of his book was Versuch einer Einleitung in die Historiam Literariam insgemein (1708). Dávid Czvittinger, who was living abroad and was a young German-speaking man from Banská Štiavnica, compiled and published the data of 250 Hungarian writers for this purpose and published them in a lexicon-like compilation (Specimen Hungariae Literatae, Frankfurt-Leipzig, 1711) (see Nemeskürty, 2001, pp. 311-312).

The contempt of the Hungarians was fueled by the widely held opinion that the Hungarians have no future and absorption is their fate. This opinion was made internationally known by Herder, who wrote: "The language of a small number of Hungarians wedged among others will not be discovered after centuries" (German title: Ideen zur Philosophie der Geschichte der Menschheit, 1791) (quotation from Nemeskürty, 2001, p. 312). However, history has refuted this view in the short term. The Hungarians were strengthened by taking advantage of the measures set by Hungarian Queen Mária Teresa (she was not only the wife of the King) to alleviate the colonial dependence. It resulted in, that at the beginning of the twentieth century, with the reform movement, the Hungarians were at the forefront of development in Southeast Europe.

Perhaps the most comprehensive opinion, driven by contempt and destatation, was expressed by Lipót Alajos Hoffmann in his book Nineveh during the time of the 1790 Reform Assembly. (By the way, he was a paid secret agent of Leopold II.) This was summed up by Tibor Eckhardt as follows: "According to the Hungarian nobleman, Corpus Juris contains everything, that you need and Hungarian land creates 


\section{György Jenei: State Sovereignty and National Identity in Hungary}

everything, that you need. You do not need foreign science. Ignorance is national virtue and bad news is created for someone who travels abroad and has learned something useful... The National Assembly is a peasant mob. A half-understood book, like Rousseau's Social Contract, provides the material for their phrases. Besides punch and wine of Tokaj, their revolution is on fire. Urbanity and science are not domestic plants" (Eckhardt, 1992, p. 105).

In the 18th century, the beginning of the ethnic minorities in the Carpathian Basin prompted the direction of popular self-awareness were coincided with the negative German opinions. The former unified "Hungarus" consciousness has disintegrated, and especially among Slovak and Romanian authors, a distorted image of a barbarian, cruel, Asian mentality and tempered Hungarian man was reflected. The Hungarian language is called the language of horses (limba cailor), which is a simple copy of the German language (Eckhardt, 1992, pp. 107-111).

An exception to this was the Polish public opinion, in which the consciousness of brotherhood was strongly and continuously present, to which the similarity of the charactistics of the two nations are connected. This was already expressed in the 16th century by Prince Wisniowiecki, as he wrote, "there are no people who are as similar to the Poles in terms of customs and nature: they have the same weapons, the same way of fighting, the same way of life, and even a few years ago their clothes were the same as the Hungarians now... So we do not agree with any nation as much as we do with the Hungarians..." (quotation from Eckhardt, 1992, pp. 112-113).

\section{SOVEREIGNTY OF THE MODERN EUROPEAN TERRITORIAL STATE AND HISTORICAL GHALLENGES}

The content of modern sovereignty has changed historically since the introduction of Westphalian sovereignty. This was linked to the historical challenges that have allowed modern, territorial European states in recent centuries to where they are in the present day. These challenges include: the national challenge; the democratic challenge; the social challenge; the current complex challenge.

- The first challenge was the development of the bourgeois nations, of which two versions of the response have emerged. The starting point of the "state-nation" version was the new revolutionary state, which, homogenized from top to the bottom, and formed a new social structure and a unified civic culture (e.g., France, and Great Britain). In the other version, this is called the "culture- nation", in which a unified citizenship was firstly created, and the civil "nation-state" (Germany, Italy) was created as a result of the social rearrangement and the emergence of a new unified culture. This eliminates the city-state power formations, the principalities in Germany, and the city-states in Italy.

Becoming a nation, whether in national or cultural versions, has resulted in state formations in which the basis and driving force of state sovereignty has been the bourgeois nation, hence these institutions are uniformly known as nation-states. The 
Civic Review · Vol. 16, Special Issue, 2020

nation-state provided an incentive framework for the Industrial Revolution, but polarizing tensions prevailed between the various strata of society. At the same time became a source of conflict between nations emerging with time differences, and the suppressing efforts of the enforcement of minority rights.

- The second challenge was the democratic challenge, to which the European state responded by developing representative democracy. This statehood institutionalized the general representation of different social strata, but at the same time failed to adequately address social differences and tensions. The responsibilities of the state have gradually expanded. Schumpeter defined the essence of representative democracy as "an institutional arrangement of political decision-making in which the demands of power are asserted by competition for the votes of the people" (quotation from Schumpeter, 1947, p. 269).

By the end of the twentieth century, the needs of social groups went beyond periodic, regular voice and occasional referendums. Institutional participation was also required in the inter-voting decision-making processes, which went beyond the framework of representative democracy (Beer, 1965). This opened a new stage in the history of modern civic democracies, called participatory or post-parliamentary democracy (Jordan and Richardson, 1987).

However, there were problems during the transition to participatory democracy. For example, consultation channels very often operated formally. They did not work regularly, and the information needed for participation in the decision-making process were not received in time. Many countries, on the other hand, are stuck at the level of representative democracy.

- The third obstacle was the social challenge for which in the 19th and 20th century the European states responded by building welfare states. Significant social groups were miserable, which did not provoke participation, but instead resistance to the emerging order.

Welfare states have built public service systems that provide minimum standards of social welfare based on equity and / or equality values. The turnaround was marked by the state of Bismarck, in which the international literature uniformly considers to be the germ form of the welfare state. This state has alleviated social tensions using the tools of state intervention. From 1881, social policy intervention began. It unfolded in two basic areas: health social security and education (Jenei, 2008, p. 160).

In the 1920s, Sweden began to build a broad, multi-sectoral social policy, ranging from family policy, health policy, education policy and to employment policy. The social welfare system re-regulated family assistance and the issue of women after Alva and Gunnar Myrdal's extremely influential book (The Crisis of Population) (Myrdal and Myrdal, 1934).

Other countries had also pursued the mitigation of social problems caused by market redistribution through state intervention. After the Great Depression of 1933, President Roosevelt ordered a reduction in agricultural raising by compensating farmers in the 1933 Agrarian Act, it regulated working hours in the Industrial Recon- 


\section{György Jenei: State Sovereignty and National Identity in Hungary}

struction Act, established a minimum wage, and set up unemployment offices. During World War II, Great Britain developed a program that comprehensively enforced the state's commitment to welfare. In 1942, Lord William Beveridge (1942) developed the basic direction, and in 1949, Thomas Humphrey Marshall then articulated the "principle of social citizenship" (Marshall, 1949).

Following World War II, welfare statehood became a general unfolding trend among modern nation-states. Different types had emerged: the Anglo-Saxon, the Scandinavian, and the Residual types. What they had in common was that they created a social balance between market and state redistribution.

In this typology a special model was developed by the BRD. It was the so-called social market economy model. The essence of the social market economy was to set up a complex, comprehensive system of social security (this would be a validation of the classic socialist basic goal), but it operated this system based on a functioning system of market competition.

- This statehood is currently facing a complex challenge. The main components are the technological challenges, the economic challenges, the ecological challenges, and the demographic challenges. The European states were responding to this challenge by developing a complex strategy, and its main component is the shift from a "government" mode of operation, to a "governance" mode of operation.

The two main components of the technological challenges are the proliferation of nuclear weapons, which threatens the defence function of nation-states, and the revolution of mass communication, which leads to the development of global production strategies that have weakened the regulatory function of the nation-state (Strange, 1996).

The economic-financial challenge is manifested in the globalization of financial markets and production. This makes individual state currencies vulnerable and limits the state's role in economic governance (Stopford and Strange, 1991).

The essence of the ecological challenge is that pollution has no national borders, and even some dangers extend to the entire planet. Individual sovereign states do not have sufficient tools to deal with these problems (Goldblatt, 1997).

The demographic challenge stems from population ageing in some regions and population explosions in other regions. The consequence is that the number of refugees (famine, political persecution, human rights violations) and economic migrants have been increasing (Agnew, 1994, p. 70). This creates interdependence between the nation-states as migration destination states and requires strategic coordination in mitigating the problems caused by the population explosion.

Each challenge is of such a nature and magnitude that the nation-states can only provide an adequate and effective response if the sovereignty of each state is extended to a new component. This is because nation-state sovereignty is exercised alone, and, in isolation, and therefore cannot be effective, even for strong nation-states. State sovereignty can only be preserved if it is complemented by interdependent sovereignty. This is the only way for the nation-states to build a constructive partnership with global forces, to have the ability to deal with global threats. 
Civic Review · Vol. 16, Special Issue, 2020

\section{WHAT ARE THE PECULIARITIES OF THE HISTORY OF THE HUNGARIAN NATION-STATE?}

\section{Culture national beginning}

Beginning with the reform period, the Hungarians chose the "culture-nation" approach version, which was comparable to that of the Germans. Like the Germans, the social base of this process was heterogeneous. In the Hungarian Reformation, not only the bourgeoisie was strengthened, but also the nobility became the main driving force for the development of the culture nation.

Hungarian culture developed to an extent of epoch-making significance. Hungarian craftsmen toured Germany and France at their young age; they worked there and trained themselves. The works of the poetic generations (Csokonai, Berzsenyi, Kölcsey, Vörösmarty, Petófi, Arany and others) were and are internationally recognized. The European mathematical prince Gauss appreciated the mathematical activities of Farkas and János Bolyai (father and son). Beethoven was often among the Hungarians, giving concerts in Pest, Buda and elsewhere. Schubert also liked to spend several summers with the Hungarians. Hungarian folk music gained European fame and it became the musical mother tongue of Hungarians. Theatres, publishing companies, newspapers and literary magazines started their operations. The Hungarian Academy of Sciences was founded.

In the Habsburg Empire, however, Hungarians were still considered second-class subjects. Their aspirations were suppressed in a variety of ways. An excellent example of this was at the beginning of the 19th century, during the reign of Emperor Francis I. It was described by historian Gyula Szekfú as follows: "Cabinet absolutism under Francis was actually a police domination, and this marks a really low level compared to the era of Maria Theresa... He sets up a secret cabinet so that the opened letters get to his desk as quickly as possible" (quotation from Nemeskürty, 2000, p. 100). In 1814, two thousand five hundred Hungarian books were banned and condemned for destruction, which were published between 1790 and 1813. The transformation of the Hungarian language into a national language was also followed hostilely. An example of this was that the famous German publisher, Corta, issued a tender with the title: "Is the Hungarian language suitable for the expression of modern concepts of public administration, trade, culture, industry and science?" Half of the applicants considered the Hungarian language unsuitable for this, whilst 5 recommended the Hungarian language. Of course, the result of the tender was not even announced. Among the applicants was Ferenc Kazinczy, who later became the leading figure of the Hungarian language renewal movement.

During the Revolution and War of Independence of 1848-1849, the short-established sovereign Hungarian state, were defeated by the Habsburgs with the support of the Russian Tsar's troops.

After the brutal retaliation, the Habsburg Empire set the goal of destroying Hungarian identity, as Prime Minister Schwarzenberg put it: "Please, what is a Hungarian 


\section{György Jenei: State Sovereignty and National Identity in Hungary}

nation? These have always been rebels who must be destroyed; they must be rendered harmless once and for all" (quotation from Nemeskürty, 1981, p. 11). Heinrich Friedjung formulated the conceptual basis of this goal even in 1908 - during the AustroHungarian Monarchy - as follows: "the name and concept of the Austro-Hungarian Monarchy is unhistorical. Hungary was part of Austria" (qutation from Nemeskürty, 1981, p. 10). According to him, at the end of the Middle Ages, Hungary was destroyed and considered to have been militarily conquered since 1686 .

In 1850, Julian Chownitz published a book in Bamberg titled Handbuch für Auswanderer nach Ungarn (Handbook for Emigrants to Hungary), in which he considered the colonization of Hungary necessary and justified it as follows: "Hungarians received all the good from the Germans; the blessings of culture can also be attributed to them; when Hungarians roamed somewhere in the Dniester region, German cities were already flourishing in today's Hungary. Therefore, the settling Germans must not believe that they are guests here; therefore, Hungarians should not be considered hosts. Hungarians are only backward natives who can hardly wait for the blessings of German civilization” (quotation from Nemeskürty, 1981, pp. 14-15).

\section{Turn in the direction of state nation}

The establishment of the Austro-Hungarian Monarchy marked a turning point. The Hungarians gained shared sovereignty within the empire. However, this was not nation-state but state-nation sovereignty. The typical problems of state-nation aspirations arose. In the course of Hungarian history, social tensions arose, as consequence of unparalleled technical and economic development. This generated mass emigration. The suppression of the autonomy demands of national minorities had exacerbated minority-ethnic tensions.

The Hungarian government of the Austro-Hungarian Monarchy responded late to the democratic challenge. Universal, equal, and secret suffrage was already introduced in Austria already in 1907, but not in Hungary. This shortcoming and other barriers of democracy persisted even in Hungary, which regained its sovereign statehood after 1920. The chances of a democratic transition were opened up, after the 1945 elections, but they were destroyed by Soviet military dominance by cruel means and with the support of smaller Hungarian groups. Until 1989 the political system was characterized by dictatorship. Although this was alleviated, but the one-party system made internal sovereignty impossible until 1989, and limited sovereignty was declared by the Soviet-Union based on proletarian internationalism, which prevented external sovereignty.

In Hungary, the response to the social challenge had also deficits. Land distribution was not accomplished and due to high levels of poverty and, the country became socially vulnerable, which was exploited by the expansive Hitlerian empire. Social contradictions tore up the social base of the political system. Poverty remained burdened with unresolved problems during the dictatorship period. 
Civic Review · Vol. 16, Special Issue, 2020

\section{The current situation in the European Union}

The European Union is an institution without historical precedent. It is a combination of confederate and federal components. Strenghtening interdependent sovereignty is therefore the result of initiatives from top-down and from bottom-up at the same time. The question is how the inevitable tensions between the two different initiatives can be reduced or eliminated.

Top-down initiatives, especially when they linked to economic coercion and political attacks cannot be effective because they limit or diminish the sovereignty of nationstates. This weakens the Union's ability to respond to global challenges. The result of the "top-down" process is sometimes effective, but there are cases when it is only formally declared and accepted. In that case a real danger is the creation of a "paper palace".

The means of mutual respect and purposeful dialogue between the nation-states, based on facts and mutual knowledge and recognition of interests, can only be achieved through joint, coordinated action and the development of strategies. This way it is possible to develop the interdependent dimension of state sovereignty in conjunction with the enforcement of popular sovereignty.

A European United States project based on economic coercion, political blackmail, or ideological homogenization-, limits and violates the sovereignty of European nationstates. At the same time, it violates European historical traditions. The rebuke of Sándor Márai, which he wrote in his 1942 article titled Röpirat a nemzetnevelés ügyében (Leaflet on the Issue of National Education), is still relevant, as he writes: "The greatness and destiny of Europe has always been and will be that peoples of different cultures, past, racial and linguistic differences differ in the struggle for the level and survival of their present and future, and it is this difference that gives real strength and character to the common European effort... A Europe whose inhabitants speak a common language, whose peoples have lost their historical self-consciousness, their people's ambition, would cease to be Europe. Europe's strengths are diversity, opposition, debate, remembrance, proof and difference" (quotation from Nemeskürty, 1996, p. 167).

Lord Dahrendorf also considers the sovereignty of European states to be essential, as he writes: "The essence of Europe is to be made up of states of different economic, political and cultural natures. Europe must not be condemned to be a certain kind of centralized United States... Unfortunately, the Union is beginning to ignore individual cultures... However, this makes no sense. The European Union has never defended the interests of anyone. Answers can only be national in nature. Different countries can only have their own responses" (qutotation from Nemeskürty, 1996, p. 167).

\section{HUNGARIAN STATE SOVEREIGNTY \\ AND ITS CURRENT ALTERNATIVES}

After 1989, a pluralist democracy based on a multi-party system was established within the framework of the rule of law in Hungary. The legal-institutional conditions for this were created and legitimized in free elections from 1990 on. External sovereignty 


\section{György Jenei: State Sovereignty and National Identity in Hungary}

has been strengthened with our memberships in various international organizations (OECD, etc.). Our membership in the European Union internationally legitimised and institutionally accepted the Hungarian legal state, the pluralist democratic political system and the regulated market economy.

Nevertheless, according to the majority votes of the European Parliament, the greater part of Hungarians - with a two-third majority - have supported a political force in the last decade and still does today, which violates democracy and the rule of law. In other words, the overwhelming majority of Hungarians support dictatorial political power. This view is regularly expressed by influential Western media and international networks that call themselves civil institutions. According to these opinions, Hungarians are not ripe for democracy.

This contempt is reflected in the greater part of the resolutions of the European Parliament, in statements by politicians, being in leading positions in the European Union, in the writings of influential newspapers and magazines, and in radio and television programs, which conclude that they should enforce the rule of law, the democracy, and the freedom of expression instead of Hungarians. In other words, Hungarians are considered second-class people and this statement have been expressing this for 10 years, regularly.

This contemptuous-condemning position is essentially a political-ideological doctrine. It is not supported by any violation of international law or European Union law that can be proven against Hungary. Nor is it its aim, to influence the public opinion of each Member State, and this endeavour is not ineffective. Opinions are divided on the above-mentioned issues of wide extent. This opinion also affects in Hungary. It provokes both agreement and rejection. In some cases, the aspirations and criticisms of the Hungarian government's opposition appear in a coordinated manner in the domestic and international media.

The crucial question for the near future is at what levels interdependent sovereignty will be strengthened and how the relationship between each level will develop. The strength of the aggression of the political-ideological pressure of the European Union, the further reduction of the European Union's weight in the world economy, or the instability of disputes between Member States will help to strengthen the identity with the phrase "leave the European Union". In extreme cases, centrifugal forces are set in motion that could trigger the disintegration of the European Union.

It helps to strengthen the so-called 'United States of Europe' identity, when federal features are pushed into the background or to secondary position to confederate features This identity and its social support favour interdependent sovereignty at the EU level over regional, for instance Central European interdependent sovereignty, and the internal clashes weakens in the Hungarian public life the power of national cooperation.

The identity with the so-called "cultur nation" and "Hungarian state sovereignty" identity gets stronger if the strengthening of the Union in the European Union is based on "bottom-up" cooperation, the regional interdependent sovereignty of the member states around Poland will gaining strength, and the economic and social 
Civic Review · Vol. 16, Special Issue, 2020

cohesion of the Hungarians living in the Carpathian Basin will establish even closer links based on the improvement of the relations to the neighbouring countries. Otherwise, if we would leave alone, it is impossible to provide an effective response to global challenges.

There is a chance for all three Hungarian identities to be strengthened. It is likely that the uncertainties that characterize the current situation, and the threatening question marks, will be permanent in the European Union. In addition to the influence of global forces and European Union institutions, the purposeful and actionoriented cooperation of the Hungarians is also an equal factor in shaping the conditions. At some point of junction, the alternatives that determine the reciprocal power relations of the three identities are already foreseeable.

The first point is whether the development of federal features in the European Union will be dominant and will be forced on the Member States "from above", or whether the interdependent sovereignty of the Member States determines the relationship between federal and confederate features.

The second point is how the character of NGOs evolves. Is the influence of civil society on NGOs growing or is the role of foreigner-funded NGOs strengthening among the civil organizations?

The third point is that, according to Helmut Schmidt's terminology, "unbridled pursuit of profit as a system" called by him "predatory capitalism" will remain dominant. Schmidt devotes an entire chapter to this issue in his memoir, in the chapter titled Predatory Capitalism. What Can We Do About It (Schmidt, 2011). The global forces will be able to bring the countries of the Euro-Atlantic cultural circle under its growing and unilateral political influence through the operation of a mechanized fossil of the European bureaucracy, or will nation-state be able to renew the role of social communities based on new values and social policy ethics; and based on the regular, institutional involvement of community organizations with full autonomy in the management of public affairs?

The fourth point is whether the degeneration of democracy towards demagogy continues (Aristotle considered this degeneration inevitable) or the fulfilment of popular sovereignty becomes a determining factor (this is what Aristotle calls "politea" or moderate popular rule, which he defines as follows): "It is clear, then, that a political community that relies on the middle class is the best one, and the city-states in which the middle class is populous can be governed correctly" (Arisztotelész, 1984, p. 194).

The fifth point is, to what extent does unrestricted immigration to Europe lead to labor market integration and to what extent do it lead to the extension of parallel societies? What will be the impact of immigration on terrorism? Is it spreading? And to what extent the practice of Saudi Arabia will be copied, which allows to enter its country only when you have a valid employment contract and requires you to leave the country when the employment contract expires?

The sixth point is whether Hungarian sovereignty will be supported by a strong, actionable national coalition, or will - divisions with the support of social demagogy be able to weaken the sovereignty of the Hungarian state? 


\section{György Jenei: State Sovereignty and National Identity in Hungary}

\section{Notes}

1 At the part on the challenges to the sovereign state I followed the orientation of the book Jönsson et al., 2000.

2 At the chapter of the paper on the theoretical discussion regarding state sovereignty, I quoted the relevant passages of the book Kunzmann et al., 1999.

3 On the theory of Jean Bodin and Johannes Althusius passage quoted from Kunzmann et al., 1999, p. 101 and Bodin, 1987.

\section{REFERENGES}

Agnew, J. (1994): The Territorial Trap: The Geographical Assumptions of International Relations Theory. Review of International Political Economy, Vol. 1, No. 1, 53-80, https://doi.org/10.1080/09692299408434268.

Arisztotelész (1984): Politika [Aristotle: Politics]. Gondolat Kiadó, Budapest.

Babits, M. (1939): A magyar jellemről [On the Hungarian character]. In: Szekfú, Gy. (ed.): Mi a magyar? [What is Hungarian?]. Magyar Szemle Társaság, Budapest, 13-36.

Beer, S. H. (1965): Modern British Politics. Faber\&Faber, London.

Beveridge, W. (1942): Social Insurance and Allied Services (Beveridge Report). His Majesty's Stationery Office, London.

Bodin, J. (1987): Az államról [On the state]. Gondolat Kiadó, Budapest.

Conze, W. and Boldt, H. (1990): Staat und Soverenität. In: Brunner, O.; Conze, W. and Koselleck, R. (eds.): Geschichtliche Grundbegriffe. Historisches Lexikon zur politisch-sozialen Sprache in Deutschland. Vol. 6, KlettCotta, Stuttgart, pp. 4-154 (see Jönsson et al., 2000, p. 76).

Deér, J. (2007): Pogány magyarok, keresztény magyarok [Pagan Hungarians, Christian Hungarians]. Attraktor Kiadó, Máriabesnyô-Gödöllô (reprint of 1938 edition).

Eckhardt, S. (1992): A magyarság külföldi képe [The foreign portrait of the Hungarians]. In: Szekfú, Gy. (ed.): Mi a magyar? [What is Hungarian?] Helikon, Budapest, 87-136, (reprint of 1939 edition).

Goldblatt, D. (1997): Liberal Democracy and the Globalization of Environmental Risks. In: McGrew, A. (ed.): The Transformation of Democracy? Polity Press, Cambridge (see Jönsson et al., 2000, p. 76).

Gombocz, Z. (1921): A bolgár kérdés és a magyar hun-monda [The Bulgarian question and the HungarianHun legend]. Magyar Nyelv, Vol. 17, January-March, 15-21.

Grotius, H. (1973): A háború és a béke jogáról [De iure belli ac pacis libri tres (1625)]. Kriterion Könyvkiadó, Bukarest (quotation from Kunzmann et al., 1999, p. 101).

Györffy, Gy. (1999): A székelyek eredete és településük története [The origin of the Szeklers and the history of their settlement]. In: Mályusz, E.: Erdély és népei [Transylvania and its peoples]. Maecenas Könyvkiadó, Budapest, 37-87.

Hobbes, T. (1999): Leviatán, vagy az egyházi és világi állam formája és hatalma [Leviathan or The Matter, Form and Power of a Common-Wealth Ecclesiasticall and Civil (1651)]. Kossuth Könyvkiadó, Budapest (quoted by Kunzmann et al., 1999, p. 117).

Hóman, B. and Szekfú, Gy. (1935): Magyar történet IV. [Hungarian History]. Királyi Magyar Egyetemi Nyomda, Budapest.

Hóman, B. and Szekfú, Gy. (1941): Magyar történet I. [Hungarian history I.]. Királyi Magyar Egyetemi Nyomda, Budapest.

Hóman, B. (2010): A magyar hún-hagyomány és hún-monda [The Hungarian hun tradition and the hun legend]. Attraktor, Máriabesnyô-Gödöllő (reprint of 1925 edition).

Hume, D. (1973): Tanulmány az emberi értelemról [Essays Moral, Political and Literary (1748)]. Magyar Helikon Könyvkiadó, Budapest (quoted by Kunzmann et al., p. 117).

Jenei, Gy. (2008): Bevezetés a társadalompolitikába [Introduction to societal policy]. Aula Kiadó, Budapest. Jordan, A. G. and Richardson, J. J. (1987): British Politics and the Policy Process. Unwin Hyman, London (see Jönsson et al., 2000, p. 76). 
Jönsson, C.; Tägil, S. and Törnqvist, G. (eds.) (2000): Organizing European Space. Sage Publications, London. Keresztury, D. (1992): A magyar önismeret útja [The way of Hungarian self-identity). In: Szekfú, Gy. (ed.): Mi a magyar? [What is Hungarian?] Helikon, Budapest (reprint of 1939 edition).

Kunzmann, P.; Burkard, F. P. and Wiedmann, F. (1999): Atlasz. Filozófia [Atlas 1. Philosophy]. Athenaeum Kiadó, Budapest.

Locke, J. (1986): Értekezés a polgári kormányzat igazi eredetéról és céljáról [Two Treatises of Government (1689/1690)]. Gondolat Kiadó, Budapest (quoted by Kunzmann et al., 1999, p. 121).

Marshall, T. H. (1949): Citizenship and Social Class. Alfred Marshall Lectures, Cambridge.

Myrdal, A. and Myrdal, G. (1934): Kris i Befolkningsfragan [Crisis in the population question]. Bonniers, Stockholm.

Nemeskürty, I. (1981): Parázs a hamu alatt [Embers under the ashes]. Magvetô Könyvkiadó, Budapest.

Nemeskürty, I. (1994): Múltunk a jelenben [Our past in the present]. Patent Nyomda és Kiadóvállalat, Uzhhorod.

Nemeskürty, I. (1996): Meddig várjunk? [How long to wait?]. Szabad Tér Kiadó, Budapest.

Nemeskürty, I. (2000): Kis magyar müvelódéstörténet [Short history of the Hungarian culture]. Szent István Társulat, Budapest.

Nemeskürty, I. (2001): Mi, magyarok [We, Hungarians]. Akadémia Kiadó, Budapest.

Nemeskürty, I. (2003): Magyarnak számkivetve [Banishment to be Hungarian]. Szabad Tér Kiadó, Budapest.

Rousseau, J. J. (1947): Társadalmi szerzódés [Social contact]. Phönix, Budapest (see Kunzmann et al., 1999, p. 133).

Schmidt, H. (2011): Nyugállományban [Being on the retired list]. Európa Könyvkiadó, Budapest, pp. 278293 (original title: Ausser Dienst. Eine Bilanz by Helmut Schmidt. Siedler Verlag, München).

Schumpeter, J. A. (1947): Capitalism, Socialism and Democracy. George Allen \& Unwin, London.

Stopford, J. and Strange, S. (1991): Rival States, Rival Firms. Competition for World Market Shares. Cambridge University Press, Cambridge (see Jönsson et al., 2000, p. 76).

Strange, S. (1996): The Retreat of the State. The Diffusion of Power in the World Economy. Cambridge University Press, Cambridge, https://doi.org/10.1017/CBO9780511559143 (see Jönsson et al., 2000, p. 76).

Szabados, Gy. (2015): A korai magyar államiságról [On early Hungarian statehood]. In: Sudár, B. (ed.): Magyarok a honfoglalás korában [Hungarians in the age of conquest]. Helikon Kiadó, Budapest, 159-170.

Terbe, L. (1936): Egy európai szállóige természetrajza [Natural history of a European adage]. Egyetemes Philológiai Közlöny, Vol. 60, No. 7-12, 297-350.

Váczy, P. (2010): A hunok Európában [The Huns in Europe]. Attraktor, Máriabesnyô-Gödöllő (reprint of Váczy, P. (1940): A hunok Európában [The Huns in Europe]. In: Németh, Gy. (ed.): Attila és hunjai [Attila and his Huns]. Magyar Szemle Társaság, Budapest. 